\title{
Communication
}

[Comunicação]

\section{Evaluation of propanediol and cobalamin metabolism in the intestinal colonization and systemic invasion of Salmonella Enteritidis in laying hens} [Avaliação do metabolismo do propanodiol e da cobalamina na colonização intestinal
e na infecção sistêmica de Salmonella Enteritidis em poedeiras]

\section{J.B. Paiva ${ }^{1}$, J. Denadai ${ }^{2}$, A.M. Almeida ${ }^{2}$, P.A. Barrow ${ }^{3}$, F.O. Barbosa ${ }^{2}$, L.B.R. Alves ${ }^{2}$, M.M.S. Saraiva2 , C.J.B. Oliveira ${ }^{4}$, A. Berchieri Júnior ${ }^{2}$, O.C. Freitas Neto ${ }^{5 *}$}

${ }^{1}$ Autônomo - Campinas, SP

${ }^{2}$ Escola de Agricultura e Ciências Veterinárias - Universidade Estadual de São Paulo - Jaboticabal, SP

${ }^{3}$ School of Veterinary Medicine and Science - The University of Nottingham - Leicestershire, United Kingdom ${ }^{4}$ Universidade Federal da Paraíba - Areia, PB

${ }^{5}$ Escola de Veterinária - Universidade Federal de Minas Gerais - Belo Horizonte, MG

Annually approximately 80.3 million cases of human foodborne diseases worldwide are caused by Salmonella, specially Salmonella Enteritidis which is one of the most prevalent serotypes isolated from human and non-human sources. Products containing raw eggs or even crosscontamination of vegetables by contaminated chicken meat during manipulation are the main sources of $S$. Enteritidis to consumers (Salmonella..., 2018). In poultry, $S$. Enteritidis has been one of the most important serotypes responsible for avian paratyphoid. In young birds it is able to colonize the gut and establish systemic infection. On the other hand, infections provoked in mature birds are generally not severe, but birds become carriers and capable to vertically or horizontally transmit the microorganism for long periods (Gast et al., 2017).

Salmonella enterica uses 1.2 propanediol (1.2$\mathrm{Pd})$ as carbon and energy source throughout a vitamin $\mathrm{B}_{12}$-dependent route. 1.2-Pd is a product of the fermentation of two common pentoses, rhamnose and fucose. Within the gastrointestinal tract it can be found naturally as a metabolized product of herbal origin and also as a terminal sugar of gut mucins (Muraoka and Zhang, 2010). $\mathrm{B}_{12}$-dependent anaerobic catabolism of small molecules in the intestine may play a central role on Salmonellae physiology, enhancing gut colonization under conditions which normally induce starvation (Bobik et al., 1999).

Previous reports indicated that 1.2-Pd metabolism is important for $S$. Typhimurium during infection in both humans and murine (Klumpp and Fuchs, 2007). Based on these data, we propose to investigate herein the importance of $c o b \mathrm{~S}, c b i \mathrm{~A}, p d u \mathrm{C}, p d u \mathrm{D}$ and $p d u \mathrm{E}$ genes to $S$. Enteritidis gut colonization and systemic infection in white and brown laying-hen varieties.

In this study, Salmonella Enteritidis strain P125109 (SE) provided the genetic background to construct the mutant strains and was used as a positive control since its capability to extensively colonize the chicken gut and cause systemic infection is known (Thomson et al., 2008). The knockout of $p d u \mathrm{C}, p d u \mathrm{D}, p d u \mathrm{E}, c o b \mathrm{~S}$ and $c b i \mathrm{~A}$ genes were done by standard Lambda Red methodology (Datsenko and Wanner, 2000). Constructions of single and triple mutant strains were carried out using the plasmids pKD46, pKD3, pKD4 and pCP20 and transduction using the bacteriophage ØР22. All strains and plasmids used are shown in Table 1. Primers were designed using the CLC Sequence Viewer Software 6.3 (Bio CLC), Artemis v11 and Primer Premier 5 (Premier Biosoft International) and the sequences are available on Table 2 .

Recebido em 18 de setembro de 2019

Aceito em 17 de junho de 2020

*Autor para correspondência (corresponding author)

E-mail: oliveirocaetano@yahoo.com 
Table 1. Bacteria strains and plasmids used in this study

\begin{tabular}{|c|c|c|}
\hline Strain or plasmid & Genotype $^{\mathrm{a}}$ & Source or reference \\
\hline WT & $\begin{array}{l}\text { Wild-type } S . \text { enterica serovar } \\
\text { Enteritidis strain P129105 spontaneous } \\
\text { mutant for nalidixic acid and } \\
\text { spectinomycin }\end{array}$ & Thomson et al., 2008 \\
\hline$\Delta p d u \mathrm{CDE}$ & $\begin{array}{l}S \text {. enterica serovar Enteritidis strain } \\
\text { P129105 knockout for the gene cluster } \\
p d u C D E \text { by insertion of } \mathrm{Cm}^{\mathrm{r}} \text { cassete }\end{array}$ & This study \\
\hline$\Delta c o b S$ & $\begin{array}{l}\text { S. enterica serovar Enteritidis strain } \\
\text { P129105 knockout for the gene cobS }\end{array}$ & Paiva et al., 2011 \\
\hline$\Delta c b i \mathrm{~A}$ & $\begin{array}{l}\text { S. enterica serovar Enteritidis strain } \\
\text { P129105 knockout for the gene } c b i \mathrm{~A}\end{array}$ & Paiva et al., 2011 \\
\hline$\Delta c o b \mathrm{~S} \Delta c b i \mathrm{~A} \Delta p d u \mathrm{CDE}$ & $\begin{array}{l}\text { S. enterica serovar Enteritidis strain } \\
\mathrm{P} 129105 \text { knockout for the genes cbiA } \\
\text { and cobS and for the gene cluster } \\
p d u \mathrm{CDE} \text { by insertion of } \mathrm{Cm}^{\mathrm{r}} \text { cassete }\end{array}$ & This study \\
\hline ØР22 & Bacteriophage & Wing, 1968 \\
\hline pKD46 & $\begin{array}{l}\lambda \text { Red recombinase expression plasmid, } \\
\mathrm{P}_{\text {araB }} \text {-gam-bet-exo, } \mathrm{Amp}^{\mathrm{r}}\end{array}$ & Datsenko and Wanner, 2000 \\
\hline pKD3 & $\begin{array}{l}\text { pir-dependent plasmid, } \\
\text { recognition sites; } \mathrm{Cm}^{\mathrm{r}}\end{array}$ & Datsenko and Wanner, 2000 \\
\hline pCP20 & FLP-recombinase plasmid; $\mathrm{Cm}^{\mathrm{r}}, \mathrm{Amp}^{\mathrm{r}}$ & Datsenko and Wanner, 2000 \\
\hline
\end{tabular}

Table 2. Oligonucleotide sequences $5^{\prime}-3^{\prime}$ used for polymerase chain reaction (PCR) in this study

\begin{tabular}{|c|c|}
\hline Primer & Sequence $5{ }^{\prime}-3^{\prime}$ \\
\hline $\mathrm{C} 1 \mathrm{~F}$ & ttatacgcaaggcgacaagg \\
\hline $\mathrm{C} 2 \mathrm{R}$ & gatcttccgtcacaggtagg \\
\hline $\mathrm{K} 1 \mathrm{~F}$ & cagtcatagccgaatagcet \\
\hline $\mathrm{K} 2 \mathrm{R}$ & cggtgccetgaatgaactgc \\
\hline CBIA CTR F & cggtgggaagtgggttgcga \\
\hline CBIA CTR R & ggccagtgttgagggtcgcc \\
\hline 2 COBS F & gcagcggcggatgaggtctg \\
\hline 2 COBS R & gccaggtcgcaggtgtagcg \\
\hline PDU CTR F & ggtccgtcaggcggtgacet \\
\hline PDU CTR R & agccetgccgettcacgaac \\
\hline CBIA 50F & ttaaagttgggccagattaccttgataccggctggcataccgctatctgtggtgtaggctggagctgcttc \\
\hline CBIA 50R & gtctgccagccgccagtccattcctgtaacacgcggccatcgcgaaccttacatatgaatatcctccttag \\
\hline PDUCDE 50F & gtctgccagccgccagtccattcctgtaacacgcggccatcgcgaaccttacatatgaatatcctcettag \\
\hline PDUCDE 50R & atctttgcetgataacggttttcgagatcgtcggcgatagcgagcagctctcatatgaatatcctccttag \\
\hline COBS 50F & atgctcgcttttattagccgettgeccgtgccgtcacgctggtcgcagggagtgtaggctggagctgcttc \\
\hline COBS 50R & caagttcgatcgccgcgcccagcgtatcgccggtttgaccgccaagcgtaccatatgaatatcctccttag \\
\hline
\end{tabular}

For in vivo assays, laying hens at two hundred days and ten days of age of each white and brown varieties were obtained from a commercial hatchery (Table 3). Chicks were randomly divided into six groups $(n=35)$ and housed in acclimatized rooms, receiving water and feed ad libitum. On the arrival, samples of faces in the internal bottom of transport cardboard boxes were collected and processed to test for the absence of Salmonella spp. At one- day-old, chicks were orally inoculated directly into the crop with $0.1 \mathrm{~mL}$ of culture containing the mutants $(\Delta p d u \mathrm{CDE}$ and $\Delta c o b \mathrm{~S} \Delta c b i \mathrm{~A} \Delta p d u \mathrm{CDE}$ ) or the wild-type (WT) strains (Table 3). For this, the inoculate were prepared in Lysogeny Broth (LB-OXOID, UK) and incubated at $37^{\circ} \mathrm{C}$ for $18 \mathrm{~h}$ under constant shaking (150 rotations per minute) to reach approximately $10^{8}$ Colony Forming Units per $\mathrm{mL}$ (CFU/mL).] 
Evaluation of propanediol...

Table 3. Experimental design summary including number and variety of chickens, and challenge strains used in each study group

\begin{tabular}{llll} 
Group & Number of chickens & Variety & Challenge strain \\
\hline A & 35 & White & WT \\
B & 35 & White & $\Delta p d u$ CDE \\
C & 35 & White & $\Delta c o b S \Delta c b i \mathrm{~A} \Delta p d u$ CDE \\
D & 35 & Brown & WT \\
E & 35 & Brown & $\Delta p d u$ CDE \\
F & 35 & Brown & $\Delta c o b S \Delta c b i \mathrm{~A} \Delta p d u \mathrm{CDE}$ \\
\hline
\end{tabular}

Five birds per group were euthanized by cervical dislocation at two, three, five, seven, 14, 21- and 28-days post-infection (dpi) for bacterial enumeration in liver, spleen and caeca contents. Bacterial counts were estimated by serial dilution (1:10) on Brilliant Green agar (DIFCO, USA) containing spectinomycin $(100 \mu \mathrm{g} / \mathrm{ml}-$ Sigma Aldrich, USA) and nalidixic acid $(25 \mu \mathrm{g} / \mathrm{ml}-$ Sigma Aldrich, USA). Isolated colonies of the last dilution were selected and submitted to Triple Sugar Iron agar, Lysine Iron agar, Sulfide Indole Motility (SIM) tests (OXOID, UK) and agglutination with anti-Salmonella O:9 antigen and anti-Salmonella $\mathrm{H}: \mathrm{gm}$ (BIO-RAD).

The presence of SE in feces was evaluated twice a week over a month by cloacal swabs. The swabs were placed within tubes containing $2 \mathrm{~mL}$ of Selenite Broth (OXOID, UK) with $0.04 \%$ novobiocin (Sigma Aldrich, USA) (SN) and, after incubation, were streaked with Brilliant Green agar supplemented with the same antibiotics as described above, according to the respective bacterial strain. Tubes and plates were incubated at $37^{\circ} \mathrm{C}$ for $24 \mathrm{~h}$. Data on fecal shedding were compared by Chi-square Test and Statistical differences amongst viable bacteria numbers recovered from caeca contents, livers and spleens were determined using two-way ANOVA followed by Tukey's Test. Both analyses were performed using GraphPad Prism version 6.00 for Windows (GraphPad Software, La Jolla, California, USA).

To our knowledge, the operons cob/cbi and $p d u$ are located side by side in the Salmonella enterica genome. During anoxic growth condition they are induced by $1.2-\mathrm{Pd}$ and are positively regulated by the PocR and the global regulators cAMP and ArcA/ArcB (Bobik et al., 1992). It is noteworthy that the anaerobic growth of Salmonella Typhimurium on 1.2-Pd depends on both the electron acceptor tetrathionate and the endogenously synthesized $\mathrm{B}_{12}$. The degradation of $1.2-\mathrm{Pd}$ is mediated by $\mathrm{B}_{12-}$ dependent diol dehydratase (PduCDE) within a polyhedral organelle (Bobik et al., 1999) which, in turn, prevents a consequent toxicity and/or carbon loss. Thus, the intermediate product, propionaldehyde, can be converted into propionate by PduP, PduL and PduW or 1propanol by PduQ (Bobik et al., 1999). On the other hand, cobalamin is synthesized again only under anaerobiosis and the ability to synthesize and import $\mathrm{B}_{12}$ requires more than 35 genes (Richter-Dahlfors et al., 1994).

In the present study, the onset of clinical signs was at three dpi when chickens of all groups had diarrhea with traces of blood and persisted until the $12^{\text {th }}$ dpi. Moreover, mortality was not observed in any group. Mutant strains were shed amidst feces in higher number by laying hens of brown variety in comparison to WT $(\mathrm{P}<0.05)$. However, both strains were excreted at the same amount by white laying hens $(\mathrm{P}>0.05)$ (Figure 1).

At three days post-infection, gross lesions such as hepato-splenomegaly with congestion in both organs were observed. No significant difference between the recovery of WT and mutant strains in organs or in caeca content was found for chicken varieties ( $\mathrm{P}>0.05)$. Means of bacterial counts in liver, spleen and caeca contents are presented in Figure 2. 


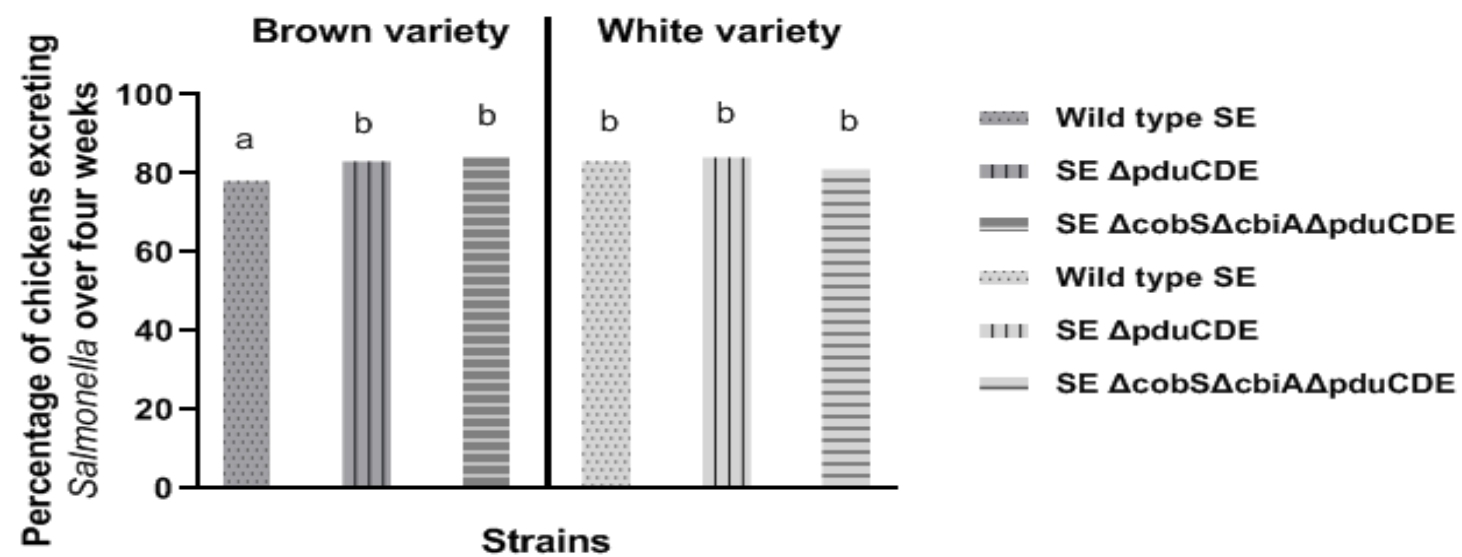

Figure 1. Fecal excretion of the wild-type Salmonella Enteritidis (WT) and mutant strains ( $\Delta p d u \mathrm{CDE}$ and $\Delta c o b \mathrm{~S} \Delta c b i \mathrm{~A} \Delta p d u \mathrm{CDE})$ by chickens assessed by cloacal swabs. Different letters on the plot mean there was statistical significance by Chi-square Test $(\mathrm{P}<0.05)$ among treatments.

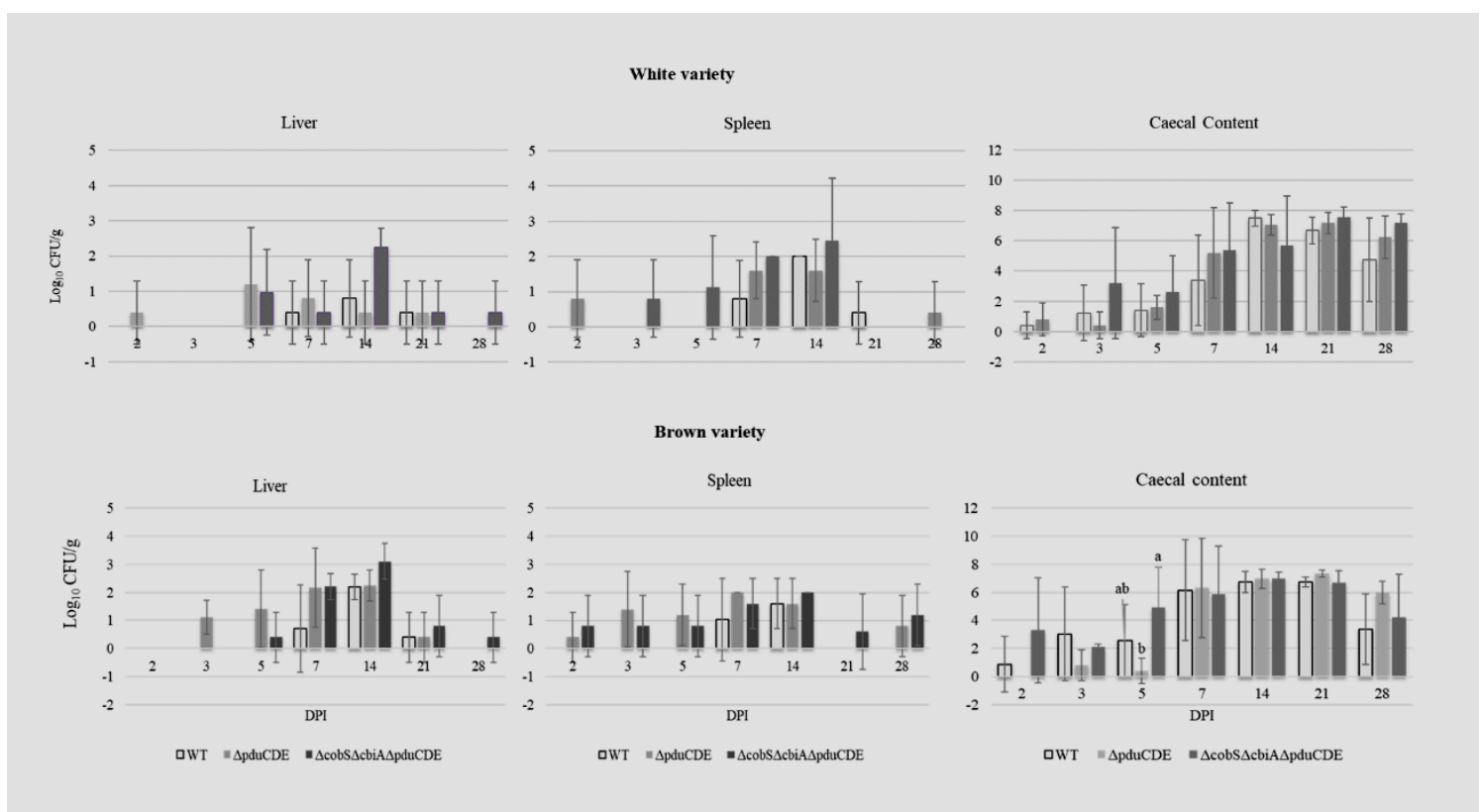

Figure 2. Bacterial counts $\left(\log _{10} \mathrm{CFU} / \mathrm{g}\right)$ in livers, spleens and caeca contents collected from chickens infected with the wild-type Salmonella Enteritidis (WT) and mutant strains ( $\Delta p d u \mathrm{CDE}$ and $\Delta c o b \mathrm{~S} \Delta c b i \mathrm{~A} \Delta p d u \mathrm{CDE}$ ) at different days post-infection.

Despite data from previous work have showed that the use of 1.2-Pd leads to advantages in the pathogenic potential of Salmonella and Listeria (Klumpp and Fuchs, 2007), we demonstrated herein that its usage is not essential for SE pathogenicity in chickens, both in the presence and absence of cobalamin synthetic pathway. No differences were found among the counts of mutant and wild-type strains recovered from liver, spleen and caeca content of both laying hens varieties. A higher number of positive cloacal swabs were recovered from brown egg layers inoculated with mutant strains in comparison to the wild type. Paiva et al. (2011) also previously found that mutations in $\operatorname{cobS}$ and $c b i$ A genes did not affect neither the ability of SE mutant strain to colonize the gut nor to provoke systemic infection in challenged chickens.

Steeb et al. (2013) analyzed several metabolic pathways used by $S$. Typhimurium during mouse 
infection. The results revealed that this bacterium was able to use at least 31 different nutrients present in host tissues by expressing versatile catabolic pathways to simultaneously exploit multiple nutrients. Possibly SE is capable of to use alternative substrates such as ethanolamine, glycogen, D-mannitol and D-sorbitol available in the chicken intestine (Kim et al., 2013). It has been demonstrated that $S$. Typhimurium can use ethanolamine by inducing the mouse gut to produce a respiratory electron acceptor (tetrathionate) which supports anaerobic growth (Thiennimitr et al., 2011). On the other hand, the chicken-restricted $S$. Gallinarum does not efficiently colonize the gut as a result of mutations affecting several metabolism genes, including $c b i$ and $p d u$ operons (Thomson et al., 2008).

In the present study, the lack of $c o b \mathrm{~S}, c b i \mathrm{~A}$ and $p d u \mathrm{CDE}$ genes in SE did not alter its ability to colonize the intestine or to cause systemic infection in both laying hens varieties. It is probably that other energy, carbon and nitrogen sources compensate the lack of 1.2-Pd usage during the pathogen infectious process in chickens. Thus, further studies are being carried out to confirm the importance of tetrathionate and ethanolamine metabolism for $S$. Enteritidis and other serovars in poultry.

\section{ACKNOWLEDGEMENTS}

We are grateful to Immunoparasitology and Pathology group of São Paulo State University, Jaboticabal, Sao Paulo, Brazil, for technical support. This work was funded by $\mathrm{CNPq}$ and grant 2011/20355-2, São Paulo Research Foundation (FAPESP).

\section{ETHICAL APPROVAL}

Experiments were performed in accordance with the ethical guidelines for the use of animals in research and approved by Ethics Committee on the Use of Animals of São Paulo State University - FCAV (Approval number: 023482/11).

Keywords: $\mathrm{B}_{12}$-dependent route, energy source, gut colonization, invasion, paratyphoid infection

\section{RESUMO}

Embora Salmonella Enteritidis (SE) seja capaz de metabolizar 1,2-propanodiol (1,2-Pd), utilizado como fonte de carbono e de energia ao longo de uma rota dependente de vitamina B12, a importância deste composto na infeção de Gallus gallus domesticus por SE permanece desconhecida. No presente estudo, foram construídos um mutante de SE sem os genes pduCDE, que codifica a propanodiol desidratase $(P d u)$, e outro contendo as deleções no pduCDE e também nos genes cobS e cbiA, responsáveis pela síntese de vitamina B12. Em seguida, avaliou-se a importância do metabolismo do 1,2-Pd em SE para colonização intestinal de infecção sistêmica de poedeiras comerciais. As estirpes mutantes de SE foram capazes de colonizar o intestino, de serem excretadas nas fezes e de invadir o baço e o fígado na mesma intensidade que a estirpe selvagem, o que sugere que os produtos dos genes pduC, pduD, pduE, cobS e cbiA não são essenciais durante infecção por Salmonella Enteritidis nessa espécie.

Palavras-chave: via dependente de $B_{12}$, fonte de energia, colonização intestinal, invasão, paratifo aviário

\section{REFERENCES}

BOBIK, T.A.; AILION, M.; ROTH, J.R. A single regulatory gene integrates control of vitamin B12 synthesis and propanediol degradation. J. Bacteriol., v.174, p.2253-2266, 1992.

BOBIK, T.A.; HAVEMANN, G.D.; BUSCH, R.J. et al. The propanediol utilization $(p d u)$ operon of Salmonella enterica serovar Typhimurium LT2 includes genes necessary for formation of polyhedral organelles involved in coenzyme B (12)-dependent 1,2-propanediol degradation. J. Bacteriol., v.181, p.5967-5975, 1999.

DATSENKO, K.A.; WANNER, B.L. One-step inactivation of chromosomal genes in Escherichia coli K-12 using PCR products. Proc. Natl. Acad. Sci. USA, v.97, p.6640-6645, 2000.

GAST, R.K.; GURAYA, R.; JONES, D.R. et al. Frequency and duration of fecal shedding of Salmonella enteritidis by experimentally infected laying hens housed in enriched colony cages at different stocking densities. Fron. Vet. Sci., v.4, p.1-6, 2017. 
KIM, Y.; SCHMIDT, B.J.; KIDWAI, A.S. et al. Salmonella modulates metabolism during growth under conditions that induce expression of virulence genes. Mol. Bio Syst., v.9, p.15221534, 2013.

KLUMPP, J.; FUCHS T.M. Identification of novel genes is genomic islands that contribute to Salmonella Typhimurium replication in macrophages. Microbiology, v.153, p.1207-1220, 2007.

MURAOKA, W.T.; ZHANG, Q. Phenotypic and genotypic evidence for L-fucose utilization by Campylobacter jejuni. J. Bacteriol., v.193, p.1065-1075, 2010.

PAIVA, J.B.; PENHA FILHO, R.A.C.; BERCHIERI JR., A. et al. Requirement for cobalamin by Salmonella enterica serovars Typhimurium, Pullorum, Gallinarum and Enteritidis during infection in chickens. Braz. $J$. Microbiol., v.42, p.1409-1419, 2011.

SALMONELLA (non-typhoidal) Geneva: WHO, 2018. Available in: http://www.who.int/en/newsroom/fact-sheets/detail/salmonella-(nontyphoidal). Acessed in: 9 Apr. 2018.
RICHTER-DAHLFORS, A.A.; RAVNUM, S.; ANDERSSON, D.I. Vitamin $\mathrm{B}_{12}$ repression of the cob operon in Salmonella typhimurium: Translational control of the cbiA gene. Mol. Microbiol. v.13, p.541-553, 1994.

STEEB, B.; CLAUDI, B.; BURTON, N.A. et al. Parallel exploitation of diverse host nutrients enhances Salmonella virulence. PLoS Pathog., v.9, p.e1003301, 2013.

THIENNIMITR, P.; WINTER, S.E.; WINTER, M.G. et al. Intestinal inflammation allows Salmonella to use ethanolamine to compete with the microbiota. Proc. Natl. Acad. Sci. USA, v.108, p.17480-17485, 2011.

THOMSON, N.R.; CLAYTON D.J.; WINDHORST D. et al. Comparative genome analysis of Salmonella Enteritidis PT4 and Salmonella Gallinarum 287/91 provides insights into evolutionary and host adaptation pathways. Genome Res., v.18, p.1624-1637, 2008.

WING, J. P. Transduction by phage P22 in a recombination-deficient mutant of Salmonella typhimurium. Virology, v.36, p.271-276, 1968. 